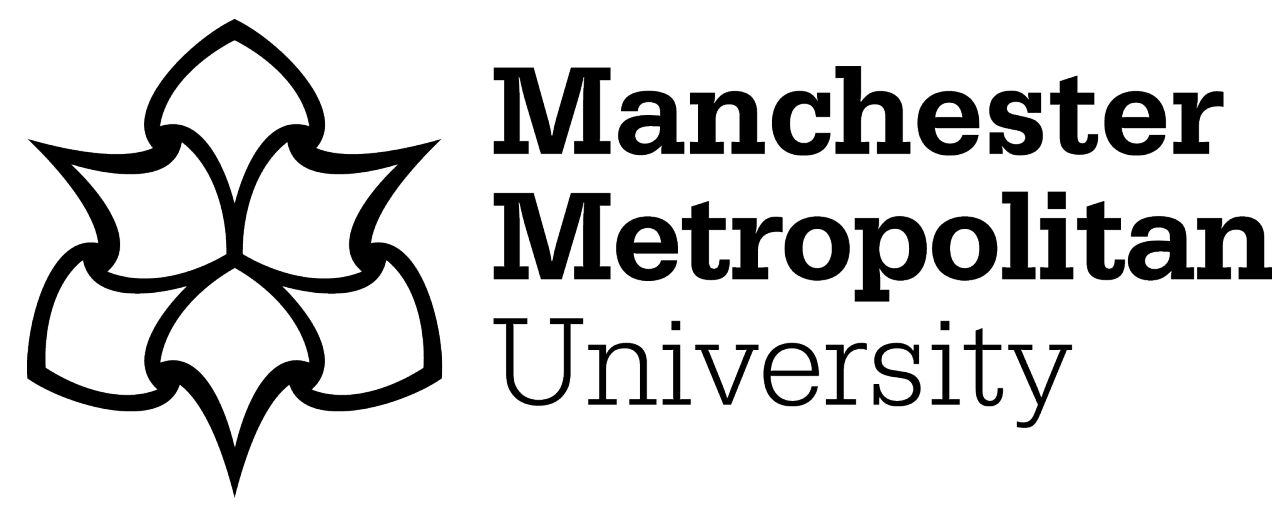

Jackson, Robert P ORCID logoORCID: https://orcid.org/0000-0002-61951067 (2020) Book review: Jan Kandiyali (ed.). Reassessing Marx's Social and Political Philosophy. Freedom, Recognition and Human Flourishing. New York and London: Routledge, 2018. ISBN 987-1-138-22620-3 (hbk). Pp. 278. £120.00. Hegel Bulletin, 41 (3). pp. 483-486. ISSN 2051-5367

Downloaded from: https://e-space.mmu.ac.uk/625580/

Version: Accepted Version

Publisher: Cambridge University Press (CUP)

DOI: https://doi.org/10.1017/hgl.2020.3

Please cite the published version 


\section{Jan Kandiyali (ed.). Reassessing Marx's Social and Political Philosophy. Freedom, Recognition and Human Flourishing. New York and London: Routledge, 2018. ISBN 987-1-138-22620-3 (hbk). Pp. 278. $£ 120.00$.}

Since 2003, the annual Marx and Philosophy Conference in London has been a showcase for original research in Marxist philosophy. Jan Kandiyali's Reassessing Marx's Social and Political Philosophy, like its predecessor, Andrew Chitty and Martin Mclvor's Karl Marx and Contemporary Philosophy (2009), curates a selection of essays developed predominantly from presentations at these events. Its twelve chapters represent more than a series of individual contributions. They are a document of a milieu of discussion around the Marx and Philosophy Society from 2012-2016. The aim of this latest volume is to provide a 'major re-evaluation of historical issues in Marx scholarship and to connect Marx's ideas with fresh debates in contemporary Anglo-American social and political philosophy' (i).

The collection is divided into four parts, covering Marx's predecessors, the theme of freedom and recognition, the relation between Marx and liberalism, and, finally, Marx's conception of communism. It offers an insightful window into the way in which Marx's thought continues to inspire innovative contributions to philosophical debates. Hegel appears as a frequent protagonist in the volume that reaffirms Hegelianism as a key 'frame of reference' for Marx's intellectual development. There is a stimulating tension in the book between those contributors who advocate elements of Hegel's thought as a corrective to the deficiencies of Marx's positions, and others who regard Marx's thought as enriching a Hegelian perspective with a more ambitious transformational project. We can discern a comparable conversation with regard to Marx's relation to liberal thought, with some authors (Moggach, Schmidt am Busch, Neuhouser) looking to incorporate a 'positive role' for liberal rights and ideals in a modified Marxian political philosophy, while others seek to re-articulate Marx's critique of liberalism. While some contributors reconstruct closely the textual argument of Marx and Hegel (Chitty), others use these philosophical positions as components to create their own constructions (e.g. Reiman's 'Marxian Liberalism'). Kandiyali's introduction supplies a helpful summary that draws out the key themes in the book, including Marx's debts to and differences with Hegel, the intersections of Marxian thought and liberalism, and the unexpectedly utopian aspects of the young Marx's vision of a good life.

The first section on Marx's predecessors, covering classical German philosophy, the Young Hegelians and the Utopian socialists, is effective in placing Marx's thought in the context of his intellectual sparring partners. Moggach explores the post-Kantian perfectionist project-those, like Schiller, Fichte and Hegel, who sought to overcome the impediments to freedom-and argues that Marx's mixed inheritance shares more of this project with his Left-Hegelian contemporaries than previously acknowledged. Moggach contends that Marx's merits stem mainly from his retention of this idealist heritage. For his part, Renault focuses our attention on the historical and logical distinctions between the Left Hegelians and the Young Hegelians. Renault reconstructs Marx's participation in these polemics over Hegel's legacy, characterizing him as 'a Left Hegelian of a Young Hegelian type' (52). Thus, Renault corrects the view of the Young Hegelians as peripheral figures in Marx's development, revealing Marx's criticisms of Hegel as deeply indebted to them. Leopold provides substance to a triumvirate of Utopian socialists, Fourier, Saint-Simon and Owen, rescuing these figures from a frequently schematic treatment in the literature. Leopold's reading enables a nuanced assessment of Marxian positions, de-reifying the traditional opposition between scientific and utopian socialism, and evaluating the extent to which well-rehearsed criticisms strike their intended target. 
The second part engages with the theme of recognition in Marx and Hegel, and the latter's concept of 'concrete freedom'. Ikäheimo finds affinities between the programmes of Hegel and Marx. At the same time, Ikäheimo argues that Marx's discussion of truly human freedom in his 'Comments on James Mill' lacks elements of Hegel's conception of concrete freedom. According to Ikäheimo, Hegel's multi-dimensional account of recognition and personhood can supplement Marx's treatment of a non-alienated way of life. This should be understood not as an 'abstract freedom', but as a way of life embedded in norms and institutions that establish truly human roles and relationships that are concretely free. Schmidt am Busch pursues this theme, investigating Hegel's relation to liberal rights. While both Marx and Hegel conceive of freedom as 'being at one with oneself in the other', Schmidt am Busch contrasts Marx's conception of 'free life-activity' with Hegel's account of the freedom of persons. For Hegel, the role of abstract right is ambivalent. It is key to the realization of modern freedom, whilst simultaneously promoting economic conditions that undermine it. For his part, Marx rejects abstract right entirely, without developing an institutional alternative that recognizes and protects human capacities. Schmidt am Busch frames Honneth's recent work on social freedom as an attempt to find a middle road between these positions. Chitty's investigation of human solidarity provides an instructive textual elaboration of the forms of self-awareness in Hegel's philosophy of spirit, and the contradictions driving the inner dynamic of these forms. Chitty identifies correspondences between the structure of Marx's conception of human emancipation, as becoming 'species-beings', and Hegel's account of the development of universal self-consciousness. While, for Chitty, Hegel's derivation has more explanatory depth, he finds that Marx's reasoning lends itself more easily to a wider treatment of 'human' solidarity.

In the third section on Marx's relation to liberalism, Neuhouser considers Marx's critique of the 'bourgeois' ideals of freedom, equality and justice. He argues that capitalist society's failure to realize these ideals leaves room for a normative commitment to them in an alternative Marxian vision. Failing to develop such a conception stems, for Neuhouser, from Marx's insufficiently Hegelian approach to the question of ideals. Marx thus neglects to provide a socially-protected space for individuals to pursue their chosen ends. Reiman addresses the impasse reached by Rawlsian thought through its combination with Marxian beliefs. He argues for a form of Marxian Liberalism that displaces ownership from its foundational position, e.g. in Left-Libertarianism. Thus, Reiman advocates a 'just state' that protects the right to liberty while minimizing social subjugation. Sypnowich provides an illuminating tour of different forms of egalitarianism, e.g. Dworkin's 'luck egalitarianism', Rawls's argument for redistribution, and their influence on Cohen and others. She argues for the elaboration of a renewed socialist vision of justice. This involves questioning the neutralist orthodoxy of contemporary (left-)liberal egalitarianism and a return to a more substantial conception of human flourishing.

In the fourth section, Brudney provides a close analysis of two elements of Marx's thought: his theory of alienation and what Brudney calls Marx's Linkage Thesis-that under communism, 'the free development of each is the condition of the free development of all' (211). Brudney delineates different ways of reading these ideas, and reconstructs them using the terminology of Rawls, Mill and Kant. Like Reiman, Brudney aims to develop a Marxian view adequate for the 21st century. For Brudney, this means reducing Marx's commitment to productivism-including the Lockean view of self-ownership, and the claim that 'human beings are essentially material producers' (218). It also means understanding the Linkage Thesis in a normative way. Kandiyali's contribution reprises the consideration of Marx's influences, arguing for a greater commonality between the ideas of Schiller and Marx than suggested by superficial appearances. In particular, Kandiyali examines their respective treatments of the deleterious effects of specialization in modern life. While contrasting Schiller's solution to this problem, aesthetic education, with Marx's emphasis on social change, Kandiyali seeks 
to underline their shared commitment to 'an uncompromising form of ethical individualism that denies that collective flourishing can come at the expense of individual self-realization' (250). Finally, Sayers discusses the return of the 'idea of communism' as a response to the prolonged crisis experienced by capitalism in the last decade. He considers the work of Alain Badiou, and the conception of history as an 'aleatory' process developed by recent French philosophy. Sayers rejects the emphasis on detachment that he finds in Badiou's ruptural notion of the Event, defending a conception of Marxism that is both dialectical and deterministic in its account of the interaction between change and continuity in history.

These readings of Marx (and Engels) are weighted towards a consideration of works written in the early 1840s, where Marx formulates the philosophical aspects of his thought most explicitly. This is understandable due to the contributors' shared focus on reading Marx philosophically. A wider reassessment of Marx's social and political philosophy could perhaps have engaged further with those studying Marx's later work (e.g. Jameson 2011, Callinicos 2014), and, more specifically, with elaborating the precise nature of the philosophical themes that persist there. Contributors may also have benefitted from bringing their significant deployment of Anglo-American thought (Rawls, Dworkin, Cohen, etc.) into dialogue with global social theory (e.g. post- and decolonial readings of Marx including Spivak 1999, Amin 2009, Banaji 2010, Chibber 2013, Harootunian 2015). This might have complemented efforts by contributors to consider the 21st-century context of Marx's thought with respect to gender (Sypnowich), social reproduction, and disability (Brudney). Overall, this volume will be of great value to scholars and advanced students interested in recent debates in Marxist philosophy. By providing a survey of this upswing in research on Marx, drawing connections with Hegel scholarship and Anglo-American philosophy, it makes an important contribution towards revivifying the significant resources that the Marxian toolbox can provide to contemporary critical thought.

\section{Robert P. Jackson}

Manchester Metropolitan University, UK

r.jackson@mmu.ac.uk 